JPdK Volume 1 Nomor 1 Tahun 2019 Halaman 84-92 JURNAL PENDIDIKAN dan KONSELING

Research \& Learning in Faculty of Education

\title{
Pengembangan Flash Card Angka Trilingual Berbasis Kearifan Lokal Untuk Pengenalan Lambang Bilangan Usia 4-5 Tahun Di Taman Kanak-kanak
}

\author{
Tri Astuti ${ }^{1}$, Elan $^{2}$, Taopik Rahman ${ }^{3}$ \\ Program Studi Pendidikan Guru Pendidikan Anak Usia Dini \\ Fakultas Ilmu Pendidikan \\ Universitas Pendidikan Indonesia Kampus Tasikmalaya \\ Email: triastuti135@gmail.com
}

\begin{abstract}
Abstrak
Telah dilakukan penelitian dan pengembangan, yang bertujuan untuk 1) mengetahui gambaran analisis kebutuhan dalam Pengembangan Flash Card Angka Trilingual Berbasis Kearifan Lokal untuk Pengenalan Lambang Bilangan Usia 4-5 Tahun, 2) mengetahui rancangan Pengembangan Flash Card Angka Trilingual Berbasis Kearifan Lokal untuk Pengenalan Lambang Bilangan Usia 4-5 Tahun, 3) mengetahui proses uji coba Pengembangan Flash Card Angka Trilingual Berbasis Kearifan Lokal untuk Pengenalan Lambang Bilangan Usia 4-5 Tahun, 4) mengetahui refleksi dari Pengembangan Flash Card Angka Trilingual Berbasis Kearifan Lokal untuk Pengenalan Lambang Bilangan Usia 4-5 Tahun. Metode penelitian yang dilakukan menggunakan metode design based research. Penelitian dilakukan di dua sekolah yaitu TK Cendrawasih 2, dan TK Cendrawasih 1. Pengumpulan data dilakukan dengan teknik wawancara, observasi, angket, expert judgement, dan dokumentasi.Uji coba dilakukan sebanyak dua kali. Uji coba pertama diikuti oleh 10 anak kelompok A TK Cendrawasih 2. Berdasarkan hasil uji coba produk, produk memerlukan beberapa perbaikan. Uji coba kedua diikuti oleh 8 anak kelompok A TK Cendrawasih

Berdasarkan hasil uji coba dilakukan refleksi terhadap produk. Hasil refleksi menunjukan nahwa produk dapat digunakan sebagai alternative media pembelajaran, yang memberi kemudahan kepada guru untuk menyampaikan materi mengenai pengenalan lambang bilangan secara variatif melalui Flash Card yang dipadukan dengan unsur-unsur kearifan lokal. Produk akhir berupa Flash Card Angka Trilingual Berbasis Kearifan Lokal untuk Pengenalan Lambang Bilangan Usia 4-5 Tahun di Taman Kanak-kanak.

Kata Kunci: Flash CardAngka, trilingual, kearifan lokal, lambang bilangan
\end{abstract}

\begin{abstract}
Research and development has been carried out, which aims to 1) find out the description of needs analysis inDevelopment Flash Card Number Trilingual Based on Local Wisdom for the Identification of Age Numbers 4-5 Years, 2) find out the design ofDevelopment Flash Card Number Trilingual Based on Local Wisdom for Introduction to Number Symbols Age 4-5 Years, 3) knowing the trial process ofDevelopment Flash Card Number Trilingual Based on Local Wisdom for Introduction to Symbols for Ages 4-5 Years, 4) knowing the reflections ofDevelopment Flash Card Number Trilingual Based on Local Wisdom for Introduction to Age Number Symbols 4- 5 years. The research method used is themethod design based research. The research was conducted in two schools namely TK Cendrawasih 2 , and TK Cendrawasih 1. Data collection was done by interview, observation, questionnaire, expert judgment, and documentation. The trial was conducted twice. The first trial was attended by 10 children in the A TK Cendrawasih group 2. Based on the results of the product trial, the product needed several improvements. The second trial was attended by 8 children in the A TK Cendrawasih group 1. Based on the results of the trial, reflection was made on the product. The results of the reflection show that the product can be used as an alternative learning medium, which makes it easy for teachers to deliver material about the introduction of various numbers of symbols through Flash Cardsthat are combined with elements of local wisdom. The final product in the form of Flash Cards Number Trilingual Based on Local Wisdom to Recognize 4-5 Years Old Age Symbols in Kindergarten.
\end{abstract}





\section{PENDAHULUAN}

Salah satu model pembelajaran di taman kanak- kanak untuk meningkatkan kemampuan pengenalan lambang bilangan anak usia dini, yaitu melalui bermain Flash Card (kartu kata). Permainan kartu ini merupakan salah satu jenis permainan dimana kartu tersebut ditunjukan berulang kali pada anak disertai bunyi bacaannya. Menurut Arsyad (2006, hlm. 34), flash cardadalah kartu kecil yang berisi gambar, teks, atau tanda simbol yang mengingatkan atau menuntun siswa kepada sesuatu yang berhubungan dengan gambar itu.Ukuran Flash Card itu sendiri dapat disesuaikan dengan kebutuhan atau besar kecilnya kelas yang dihadapi.

Pengenalan lambang bilangan pada anak usia dini diperlukan berbagai cara dalam proses pembelajaran, salah satunya adalah dengan menggunakan berbagai media pembelajaran Flash Card agar anak lebih tertarik dan antusias dengan hal-hal baru, sehingga dengan hal-hal baru tersebut anak akan lebih mudah dalam menerima informasi. Arsyad, A. (2005, hlm. 119) menjelaskan bahwa kartu huruf adalah kartu abjad yang berisi gambar, huruf, tanda simbol, yang meningkatkan atau menuntun anak berhubungan dengan simbol-simbol tersebut. Model permainan dengan kartu kata bergambar lebih berpengaruh terhadap kemampuan membaca awal ( Lestari, 2014; Sundari, 2013).

Pengembangan media pembelajaran Flash Card dalam penelitian ini, peneliti akan memasukkan unsur-unsur kearifan lokal Jawa Barat, yakni dengan memasukkan kata-kata dari bahasa Sunda yang sering dipergunakan oleh anak usia dini dalam bercakap-cakap bersama teman sebayanya, peneliti juga akan memasukan

berbagai gambar-gambar kearifan lokal Jawa Barat yang diharapkan mampu meningkatkan minat belajar siswa. Lebih jauh, hasil pengembangan media ini dapat dipergunakan menjadi salah satu variasi model mengajar guru untuk pengenalan lambang bilangan anak usia dini.Berdasarkan penjelasan diatas peneliti bermaksud untuk mengembangkan media pembelajaran berupa Flash Card Angka Trilingual Berbasis Kearifan Lokal untuk Pengenalan Lambang Bilangan Usia 4-5 Tahun.

\section{Pengertian Anak Usia Dini}

Menurut NAEYC (National Association for the Education of Young Children) dalam Sofia Hartati (2005, hlm. 7) anak usia dini merupakan sekelompok individu yang berada dalam rentang usia 0-8 tahun, sedangkan menurut Undang-undang Nomor 20 Tahun 2003 Pasal 1 angka 14 tentang Sistem Pendidikan Nasional dalam Permendiknas No. 58 Tahun 2009 menyatakan bahwa; Pendidikan Anak Usia Dini (PAUD) adalah suatu upaya pembinaan yang ditujukan kepada anak sejak lahir sampai dengan usia enam tahun yang dilakukan melalui pemberian rangsangan pendidikan untuk membantu pertumbuhan dan perkembangan jasmani dan rohani agar anak memiliki kesiapan dalam memasuki pendidikan lebih lanjut.

Dari pernyataan diatas dapat disimpulkan bahwa anak usia dini adalah anak yang berusia 0-8 tahun yang sedang mengalami proses pertumbuhan dan perkembangan. Sedangkan, di Indonesia anak usia dini adalah anak yang berada pada rentang usia lahir sampai 6 tahun yang sedang mengalami proses pertumbuhan dan perkembangan, baik fisik, maupun mental.

\section{Kemampuan Mengenal Lambang Bilangan}

Lingkup perkembangan kognitif pada anak usia 4-5 tahun yang perlu dikembangkan

dalam kegiatan pembelajaran salah satunya ialah pengenalan konsep bilangan dan lambang bilangan. Pengenalan konsep bilangan dan lambang bilangan pada anak TK kelompok A adalah anak mampu untuk membilang banyak benda 1-10, membilang/menyebut urutan bilangan 1-10, menunjuk lambang bilangan 110, meniru lambang bilangan 1- 10, dan menghubungkan /memasangkan lambang bilangan dengan benda-benda sampai 10 (anak tidak disuruh menulis). Adapun kemampuan mengenal lambang bilangan dalam penelitian ini adalah kemampuan anak menyebutkan lambang bilangan 1-10, dan membilang banyak benda 110.

\section{Media Pembelajaran}

a. Pengertian Media Pembelajaran Menurut Sadiman (dalam Ruswandi,

2008, hlm.9) "media berasal dari bahasa latin, merupakan bentuk jamak dari medium yang secara harfiah berarti perantara atau pengantar".Jadi, dapat dikatakan bahwa media adalah perantara atau pengantar pesan berupa materi pembelajaran dari pengirim atau media ke penerima pesan atau siswa.

Menurut Daryanto (2016, hlm. 5-6) secara umum dapat dikatakan media mempunyai kegunaan, antara lain:

1) Memperjelas pesan agar tidak terlalu 
verbalitas.

2) Mengatasi keterbatasan ruang, waktu tenaga dan daya indra.

3) Menimbulkan gairah belajar, interaksi lebih langsung antara murid dengan sumber belajar.

4) Memungkinkan anak belajar mandiri sesuai dengan bakat dan kemampuan visual, auditori dan kinestetiknya.

5) Memberi rangsangan yang sama, mempersamakan pengalaman dan menimbulkan persepsi yang sama.

b. Jenis Media Pembelajaran

Leshin, Pollock Reigeluth (dalam Arsyad, hlm 36) mengklasifikasikan media kedalam lima kelompok, yaitu:

1) Media berbasis manusia.

2) Media berbasis cetak.

3) Media berbasis visual.

4) Media berbasis audio visual.

5) Media berbasis komputer. Pengerjaaan dengan bantuan computer, video interaktif, hypertext.

Sementara itu Yudhi Munadi (2013, hlm. 54-57) mengelompokkan media dalam pembelajaran dalam empat kelompok besar berdasarkan keterlibatan indera, yaitu:

1) Media Audio

2) Media Visual

3) Media Audio-visual

4) Multimedia

\section{Flash Card Angka Trilingual Berbasis Kearifan Lokal}

a. Pengertian Flash Card

Flash Card merupakan kartu belajar kecil yang berisi gambar, teks, atau tanda simbol yang efektif mempunyai dua sisi dengan salah satu sisi berisi gambar, teks, atau tanda simbol dan sisi lainnya berupa definisi, keterangan gambar, jawaban, atau uraian yang membantu mengingatkan atau mengarahkan siswa kepada sesuatu yang berhubungan dengan gambar yang ada pada kartu, ukurannya juga dapat disesuaikan dengan kebutuhan atau besar kecilnya kelas yang dihadapi. Maka, dapat disimpulkan bahwa Flash Card mempunyai ciri-ciri sebagai berikut:

1) Flashcard berupa kartu bergambar yang efektif.

2) Mempunyai dua sisi depan dan belakang.

3) Sisi depan berisi gambar atau tanda simbol.

4) Sisi belakang berisi definisi, keterangan gambar, jawaban, atau uraian.

5) Sederhana dan mudah membuatnya.

b. Kelebihan dan Kekurangan Media Flash Card

1) Kelebihan Media Flash Card

Media flash card tergolong dalam media visual (gambar), media Flash Card memiliki beberapa kelebihan, sebagaimana yang diungkapkan oleh Susilana dan Riyana (2009, hlm. 94) antara lain:

a) Mudah dibawa kemana-mana

b) Praktis

c) Gampang diingat

d) Menyenangkan

2) Kekurangan Media Flash Card

Kekurangan media Flash Card menurut

Kurnia antara lain:

a) Semata-mata hanya media visual.

b) Ukuran gambar seringkali kurang tepat untuk pengajaran dalam kelompok besar.

c) Memerlukan ketersediaan sumber, keterampilan, dan kesediaan guru untuk dapat memanfaatkannya.

b. Trilingual

Menurut kamus lengkap Inggris- Indonesia Trilingual (menguasai) tiga bahasa.Jadi Trilingual adalah kemampuan seseorang untuk menguasai tiga bahasa.Banyak keuntungan yang bisa didapatkan anak bilingual/multilingual.Sebuah penelitian menunjukan anak bilingual cenderung lebih cerdas, dan memiliki kemampuan analisa lebih baik dibanding anak monolingual (berkomunikasi dengan satu bahasa).Masyarakat Indonesia sangat beruntung karena dengan beragamnya

menjadi bilingual/multilingual sejak kecil.

e.Kearifan Lokal

Menurut Wikipedia kearifan lokal merupakan bagian dari budaya suatu masyarakat yang tidak dapat dipisahkan dari bahasa masyarakat itu sendiri. Kearifan lokal (local wisdom) biasanya diwariskan secara turun temurun dari satu generasi ke generasi lain melaui cerita dari mulut ke mulut. Kearifan lokal sebagai suatu pengetahuan yang ditemukan oleh masyarakat lokal mengembangkan, dan menguji kelayakan suatu produk untuk mengatasi masalah 
dalam pembelajaran. Peneliti akan mengembangkan flash card angka trilingual berbasis kearifan lokal untuk pengenalan lambang bilangan usia 4-5 tahun di taman kanak-kanak.

Adapun prosedur penelitian yang dipaparkan oleh Revees (2008) untuk metode Design Based Research (DBR), sebagai berikut:

1. Analysis of Practical Problems by Researchers and Practitioners in Colaboration (Identifikasi dan analisis masalah oleh peneliti dan praktisi secara kolaboratif).

2. Development of Solutions Informed by Existing Design Principles and Technological Innovations (Mengembangkan prototype solusi yang didasarkan pada patokan teori, design principle yang ada dan inovasi teknologi).

3. Interative Cycles of Testing and Refinement of Solutions in Practice (Melakukan proses berulang untuk menguji dan memperbaiki solusi secara praktis).

4. Reflection to Produce "Design Principles" and Enhance Solution Implementation (Refleksi untuk menghasilkan design principle serta meningkatkan implementasi dari solusi secara praktis).

\section{A. Partisipan dan Tempat Penelitian \\ 1. Partisipan}

Partisipan adalah seluruh pihak yang terlibat dalam penelitian ini. Adapun partisipan yang berperan dalam penelitian ini adalah guru kelompok Adan siswa kelompok A TK Cendrawasih 1, dan TK Cendrawasih 2.

\section{Tempat Penelitian}

Penelitian ini dilaksanakan di dua sekolah, yaitu TK Cendrawasih 1, dan TK Cendrawasih 2 Kecamatan Cihaurbeuti, Ciamis.

\section{B. Pengumpulan Data}

Teknik pengumpulan data yang dilakukan pada penelitian ini antara lain:

1. Wawancara

2 Observasi

3. Angket

4. Expert Judgement

5. Dokumentasi

A. Analisis Data

1. Tenik Analisis Data

Adapun langkah-langkah yang dilakukan dalam analisis data pada penelitian ini ialah:

a. Data Reduction (Reduksi Data)

b. Data Display (Penyajian Data) c. Conclusion Drawing/Verification

(Penarikan kesimpulan/verifikasi).

\section{HASILPENELITIAN DAN PEMBAHASAN}

\section{Analisis Kebutuhan Pengembangan Produk}

Peneliti melakukan studi pendahuluan diantaranya studi literatur untuk mencari berbagai data sebagai sumber tertulis yang relevan dengan permasalahan yang dikaji, dan studi lapangan untuk menemukan permasalahan yang terjadi dilapangan. Studi pendahuluan dilakukan dengan menggunakan wawancara secara langsung dengan tenaga pendidik di dua sekolah, yaitu TK Cendrawasih 2 yang berada di Desa Cijulang pada Hari Senin, 15 April, dan TK Cendrawasih 1 yang berada di Desa Sukahaji pada hari Kamis, 18 April 2019. Hal ini dilakukan untuk mengetahui lebih jauh tentang dasar kebutuhan media pembelajaran, khususnya mengenai pengenalan lambang bilangan anak usia 4- 5 tahun.

\section{Rancangan Produk}

Tahap rancangan desain produk ini meliputi analisis Kompetensi Inti (KI),

tertentu melaui kumpulan pengalaman dalam mencoba dan diintegrasikan dengan pemahaman terhadap budaya dan keadaan alam suatu tempat.

Kearifan lokal merupakan gagasan yang timbul dan berkembang secara terus menerus di dalam sebuah masyarakat berupa adat istiadat, tata aturan/norma, bahasa, kepercayaan, dan kebiasaan sehari- hari.

\section{METODOLOGI PENELITIAN}

Metode penelitian yang digunakan yaitu Design Based Research (DBR). Menurut Lidinillah (2012, hlm. 4), Design Based Research merupakan suatu kajian sistematis tentang merancang, mengembangkan dan mengevaluasi intervensi pendidikan (seperti program, strategi, dan bahan pembelajaran, produk, dan system) sebagai solusi untuk memecahkan masalah yang kompleks dalam praktik pendidikan, yang juga bertujuan untuk memajukan pengetahuan kita tentang karakteristik dari intervensi- intervensi tersebut serta proses perancangan dan pengembangannya.

Dari pemaparan di atas, peneliti menggunakan metode Design Based Research (DBR) karena 
sesuai dengan tujuan penelitian yaitu merancang, bahasa daerah dapatmembantu anak

Kompetensi Dasar (KD), indikator, tujuan pembelajaran, materi, pemaparan tentang komponen media flash card angka trilingual berbasis kearifan lokal untuk pengenalan lambang bilangan usia 4-5 tahun di Taman Kanak-kanak. Kemudian dilanjutka dengan menyusun storyboard,melakukan pembuatan produk, dan melakukan validasi produk oleh para ahli.

\section{a. Uji Coba Produk Tahap 1}

Peneliti melakukan uji coba tahap 1 pada kelompok A TK Cendrawasih 2 pada hari Kamis, 9 Mei 2019. Subjek penelitian pada uji coba produk ini adalah anak kelompok A yang berjumlah 10 anak dan 1 gurukelas

A. Hasil pada uji coba kelompok A TK Cendrawasih 2 yaitu efektifitas hasil belajar anak dan penilaian dari guru berupa lembar penilaian media setelah aktifitas pembelajaran menggunakan media flash card angka trilingual berbasis kearifan lokal untuk pengenalan lambang bilangan usia 4-5 tahun di taman kanak-kanak. Pada penelitian ini guru bertindak sebagai penilai dan peneliti sebagai pengajar dan juga observer.

1) Respon Anak terhadap Penggunaan Media Flash Card Angka Triligual Berbasis Kearifan Lokal diatas menyatakan bahwa hasil respon anak-anak kelompok A TK Cendrawasih 2 terhadap produk pengembangan media flash card angka trilingual berbasis kearifan lokal untuk pengenalan lambang bilangan usia 4-5 tahun di taman kanakkanak sangat baik. Terlihat dari rata-rata presentase hasil respon anak yaitu $86 \%$.

b. Uji Coba Produk Tahap 2

Peneliti melakukan uji coba tahap 2 pada kelompok A TK Cendrawasih 1 pada hari Rabu, 17 Mei 2019. Subjek penelitian pada uji coba produk ini adalah anak kelompok A yang berjumlah 8 anak dan 1 guru kelas

A. Hasil pada uji coba kelompok A TK Cendrawasih 1 yaitu efektifitas hasil belajar anak dan penilaian dari guru berupa lembar penilaian media setelah aktifitas pembelajaran menggunakan media flash card angka trilingual berbasis kearifan lokal untuk pengenalan lambang bilangan usia 4-5 tahun di taman kanakkanak. Pada penelitian ini guru bertindak sebagai guru dan peneliti sebagai pengajar dan juga observer.

1) Respon Anak terhadap Penggunaan Media Flash Card Angka Trilingual Berbasis Kearifan Lokal

Berdasarkan respon anak pada tabel

\begin{tabular}{|c|c|c|c|}
\hline \multirow{2}{*}{ No. } & \multirow{2}{*}{ Indikator } & \multicolumn{2}{|c|}{ Penilaian } \\
\hline & & Ya & Tidak \\
\hline \multirow[t]{4}{*}{1.} & $\begin{array}{l}\text { Menambah pengetahuan anak tentang } \\
\text { lambang bilangan, dan kearifan lokal } \\
\text { Jawa Barat }\end{array}$ & $75 \%$ & $25 \%$ \\
\hline & $\begin{array}{l}\text { Memperjelas materi yang } \\
\text { disampaikan }\end{array}$ & $75 \%$ & $25 \%$ \\
\hline & $\begin{array}{ll}\text { Membangkitkan } & \text { motivasi } \\
\text { belajar anak } & \\
\end{array}$ & $100 \%$ & $0 \%$ \\
\hline & $\begin{array}{l}\text { Kegiatan pembelajaran menjadi } \\
\text { menyenangkan bagi } \\
\text { anak }\end{array}$ & $100 \%$ & $0 \%$ \\
\hline \multirow[t]{4}{*}{2} & $\begin{array}{l}\text { Teks yang terdapat pada flash card terbaca } \\
\text { dengan jelas } \\
\text { oleh anak }\end{array}$ & $100 \%$ & $0 \%$ \\
\hline & $\begin{array}{l}\text { Gambar yang terdapat pada } \\
\text { flash card terlihat dengan jelas oleh anak }\end{array}$ & $100 \%$ & $0 \%$ \\
\hline & $\begin{array}{l}\text { Kombinasi gambar dan } \\
\text { tulisan mudah diingat oleh anak }\end{array}$ & $75 \%$ & $25 \%$ \\
\hline & Tampilan flash card menarik bagi anak & $100 \%$ & $0 \%$ \\
\hline
\end{tabular}




\begin{tabular}{|l|l|c|c|}
\hline 3 & Flash card mudah digunakan oleh anak & $100 \%$ & $0 \%$ \\
\cline { 2 - 4 } & $\begin{array}{l}\text { Flash card dapat digunakan anak untuk } \\
\text { belajar mandiri }\end{array}$ & $100 \%$ & $0 \%$ \\
\hline Rata-rata Presentase & $92,5 \%$ & $7.5 \%$ \\
\hline
\end{tabular}

Berdasarkan respon anak pada tabel diatas menyatakan bahwa hasil belajar anak-anak kelompok A TK Cendrawasih 1 terhadap produk pengembangan media flash card angka trilingual berbasis kearifan lokal untuk pengenalan lambang bilangan usia 4-5 tahun di taman kanak- kanak sangat baik. Terlihat dari rata-rata presentase hasil belajar yaitu 92,5\%.

Penelitian berupa pengembangan flash card angka trilingual berbasis kearifan lokal untuk pengenalan lambang bilangan usia 4-5 tahun di taman kanak-kanak ini menggunakan pendekatan kualitatif dengan metode Design Based Research (DBR) yaitu bertujuan untuk membahas temuan data di lapangan, berupa permasalahan disertasi solusi berdasarkan rumusan masalah yang telah dibuat.

\section{Deskripsi Hasil Analisis Masalah}

Berdasarkan hasil analisis masalah yang ditemukan di kelompok A TK Cendrawasih

1 dan TK Cendrawasih 1 peneliti merancang pengembangan flash card angka trilingual berbasis kearifan lokal untuk pengenalan lambang bilangan usia 4-

5 tahun di taman kanak-kanak. Menurut guru kelompok A. Berdasarkan hasil wawancara yang telah dilakukan, ditemukan beberapa fakta, permasalahan dan harapan dalam pembelajaran pengenalan lambang bilangan. Secara garis besar tujuan dari pengenalan lambang bilangan adalah untuk menfasilitasi anak dalam perkembangan kognitifnya. Adapun penggunaan media di TK memang sudah biasa dilakukan oleh guru, untuk membantu guru dalam penyampaian materi pembelajaran. Salah satu media yang digunakan adalah media Flash Card.Media flash card adalah kartu bergambar berukuran kecil yang berisi pesan. Media flash card juga digunakan guru dalam pengenalan lambang bilangan, huruf, pengenalan gambargambar seperti gambar binatang, buahbuahan, perabotan rumah dan lain sebaginya. Menurut beliau kelebihan dari media flash card itu sendiri selain membantu guru dalam penyampaian materi pembelajaran juga ukurannya yang kecil praktis untuk di gunakan karna tidak memakan tempat yang luas, selain itu juga medianya sederhana sehingga mudah utnuk dibuat. Namun media flash card itu sendiri memiliki kekurangan, pembuatan flash card yang sederhana yaitu terbuat dari bahan karton atau duplek menjadikan media tidak tahan lama, mudah terkena air dan gampang robek oleh anak. Media flash card yang ingin dikembangkan sudah sangat baik, saat ini pengenalan kearifan lokal Jawa Barat memang sedang di kenalkan di berbagai sekolah guna melestarikan adat atau ciri khas Jawa Barat. Bebagai kearifan lokal yang diperkenalkan pada media yang peneliti kembangkan diantaranya rumah panggung, kelom geulis, tutug oncom, payung geulis, kujang, angklung, pencak silat, kain batik, tari jaipong, dan wayang golek.

Berdasarkan permasalahan tersebut, peneliti merancang media media flash card angka trilingual berbasis kearifan lokal untuk pengenalan lambang bilangan usia 4- 5 tahun di taman kanak-kanak sebagai suatu solusi pada permasalahan yang telah ditemukan.

\section{Deskripsi Pengembangan Produk}

Proses pengembangan produk diawali dengan analisis kurikulum. Analisis kurikulum meliputi program pengembangan, kompetensi inti, kompetensi dasar, indikator pencapaian, tujuan pembelajaran, materi, dan mediauntuk pengenalan lambang bilangan. Setelah itu peneliti, peneliti membuat dasar pengembangan produk, yang merupakan gambaran secara keseluruhan dari media yang akan peneliti buat. Selanjutnya peneliti membuat storyboard sebagai desain media yang akan disajikan pada media flash card angka trilingual berbasis kearifan lokal.

Media flash card angka trilingual berbasis kearifan lokal untuk pengenalan lambang bilangan usia 4-5 tahun di taman kanak-kanak ini memiliki dua sisi depan dan belakang. Tampilan depan berisi tentang pengenalan lambang bilangan 110, yang dilengkapi keterangan angka 
dengan menggunakan tiga bahasa yaitu bahasa Sunda, Indonesia, dan Inggris .sedangkan untuk tampilan belakang dilengkapi dengan gambar berbagai kearifan lokal Jawa Barat dan keterangan gambarnya. Adapun berbagai kearifan lokal Jawa Barat yang di tampilkan yaitu rumah panggung, kelom geulis, tutug oncom, payung geulis, kujang, angklung, pencak silat, kain batik, tari jaipong, dan wayang golek.Media flash card angka trilingual berbasis kearifan lokal untuk pengenalan lambang bilangan usia 4-5 tahun di taman kanak-kanakterdiri dari 10 keping flash card angka 1-10 dalam satu box.

Setelah melalui tahap pembuatan produk, peneliti melakukan validasi produk oleh para ahli.Ahli yang menjadi validator merupakan ahli pada bidangnya. Berdasarkan validasi para ahli bahwa produk pengembangan media flash card angka trilingual berbasis kearifan lokal untuk pengenalan lambang bilangan usia $4-$

5 tahun di taman kanak-kanak ini layak untuk proses uji coba dengan revisi sesuai saran, selanjutnya peneliti melakukan uji coba setelah melakukan revisi produk.

\section{Deskripsi Proses Uji Coba Produk}

Proses uji coba produk dilakukan melalui dua tahap. Uji coba tahap I dilakukan pada kelompok A TK Cendrawasih 2 dengan subjek penelitian 10 anak dan 1 orang guru. Keberhasilan produk terhadap hasil belajar anak mencapai $86 \%$, hal ini dapat disimpulkan bahwa produk dapat meningkatkan perhatian dan motivasi belajar anak, sehingga anak antusias dalam proses pembelajaran. Selain itu juga peneliti mendapatkan saran dan masukan mengenai media yang peneliti kembangkan. Saran dari guru ditindak lanjut oleh peneliti dengan proses revisi produk, hasil dari revisi produk selanjutnya akan diuji coba pada tahap II.

Proses uji coba produk tahap II dilakukan dikelompok A TK Cendrawasih

1. Subjek pada penelitian ini 8 anak dan 1 orang guru, pada uji coba tahap II keberhasilan produk terhadap hasil belajar anak mencapai 92,5\%, yang sebelumnya dilakukan uji coba tahap I mencapai $86 \%$. Dari hasil uji coba menunjukan peningkatan pada hasil belajar anaksebesar 6,5\% terhadap media pembelajaran flash card angka trilingual berbasis kearifan lokal untuk pengenalan lambang bilangan usia 4-5 tahun di taman kanak-kanak.

\section{Deskripsi Refleksi Produk}

Refleksi dari pengembangan produk, yaitu menghasilkan produk akhir berupa flash card, dan buku panduan pengembangan flash card angka trilingual berbasis kearifan lokal untuk pengenalan lambang bilangan usia4-5 tahun di taman kanak-kanak. Produk ini dapat digunakan untuk pengenalan lambang bilangan 1-10, pada sisi depan media flash card menampilakan angka dengan keterangan tiga bahasa yaitu bahasa Indonesia, Sunda, dan Inggris. Sehingga dalam proses pembelajarannya guru dapat memperkenalkan angka dengan tiga bahasa. Kearifan lokal Jawa Barat yang diangkat bukan hanya memperkenakan bahasa sunda pada anak saja, namun diperkenalkan juga kearifan lokal Jawa Barat yang lain, seperti rumah panggung, kelom geulis, tutug oncom, payung geulis, kujang, angklung, pencak silat, kain batik, tari jaipong, dan wayang golek, yang peneliti kemas kedalam flash card sehingga dapat digunakan untuk materi membilang banyak benda 1-10. Hal-hal tersebut mampu meningkatkan perhatian dan juga motivasi anak selama proses pembelajaran.

Hasil akhir dari tahap pengembangan media flash card angka trilingual berbasis kearifan lokal untuk pengenalan lambang bilangan usia 4-5 tahun di taman kanakkanak ini menyebarkan produk secara terbatas yaitu di TK Cendrawasih 1 dan TK Cendrawasih 2 sebagai alternatif pilihan media pembelajaran pengenalan lambang bilangan.

\section{SIMPULAN}

Berdasarkan hasil pengembangan flash card angka trilingual berbasis kearifan lokal untuk pengenalan lambang bilangan usia 4-5 tahun di taman kanak-kanak terdapat kesimpulan sebagai berikut:

1. Pengembangan flash card angka trilingual berbasis kearifan lokal untuk pengenalan lambang bilangan usia 4-5 tahun di taman kanak-kanak dibuat berdasarkan masalah yang ditemukan peneliti ketika melakukan studi pendahuluan terkait permasalahan yang ada di taman kanak-kanak 
tersebut. Selain itu juga kajian literatur merupakan bagian dari pemecahan masalah agar mendapatkan solusi yang diharapkan. Selanjutnya peneliti melakukan pengembangan produk dengan langkah-langkah menganalisis kurikulum, merancang desain pengembangan, menyusun storyboard sebelum pembuatan media yang peneliti kembangkan. Desain flash card di rancang menggunakan aplikasi corel draw, yang kemudian dicetak menggunakan kertas id card dan mengalami proses laminating.

2. Peneliti melakukan uji validasi produk oleh tiga ahli, yaitu ahli materi, ahli media, dan ahli pedagogik. Uji validasi dilakukan untuk mengetahui kelayakan dari media yang peneliti kembangkan

sebelum media tersebut layak untuk proses uji coba di lapangan. Saran dan masukan dari para ahli sebagai bahan perbaikan terhadap flash card angka trilingual berbasis kearifan lokal untuk pengenalan lambang bilangan usia 4-5 tahun di taman kanak-kanak yang peneliti kembangkan.

3. Proses uji coba dilakukan sebanyak dua kali di sekolah yang berbeda. Data didapatkan berdasarkan respon siswa dan penilaian guru terhadap pengembangan flash card angka trilingual berbasis kearifan local untuk pengenalan lambang bilangan usia 4-5 tahun di taman kanak-kanak. Hasil uji coba produk menunjukan hasil yang baik untuk pembelajaran di taman-kanak- kanak. Walaupun pada saat uji coba pertama terdapat revisi/ produk yang dilakukan untuk memperbaiki kekurangan produk. Secara umum respon siswa dan penilaian guru terhadap pengembangan flash card angka trilingual berbasis kearifan lokal untuk pengenalan lambang bilangan usia 4-5 tahun di taman kanak-kanak layak untuk digunakan dalam proses pembelajaran.

4. Setelah melakukan validasi produk kepada para ahli, dan peneliti melakukan uji coba produk untuk menguji produk di lapangan, maka refleksi dari pengembangan produk adalah menghasilkan produk berupa flash card angka trilingual berbasis kearifan lokal untuk pengenalan lambang bilangan usia 4-5 tahun di taman kanak-kanak. Produk dikemas menggunakan box, setiap box berisi 10 keping flash card angka trilingual berbasis kearifan lokal untuk pengenalan lambang bilangan usia 4-5 tahun di taman kanakkanak.

\section{DAFTAR PUSTAKA}

Arsyad, Azhar. (2006). Media Pembelajaran. Jakarta: PT. Raja Grafindo Persada.

Daryanto. (2016). Media Pembelajaran.Yogyakarta: Gava Media

Departemen Pendidikan Nasional. (2007). Panduan Seri Model Pembelajaran di TK. Jakarta: Depdiknas.

Hartati, Sofia. (2005). Perkembangan Belajar pada Anak Usia Dini. Jakarta: Departemen Pendidikan Nasional, Direktorat Jendral Pendidikan Tinggi, Direktorat Pendidikan Tenaga Kependidikan dan Ketenagaan Perguruan Tinggi.

Kamus Lengkap. (2018). Trilingual. [Online] Diakses dari http//:kamuslengkap.id/kamus/inggr is-indonesia/arti-kata/trilingual/

Lidinillah, D. A. M. (2012). Educational Design Research: a Theoretical Framework for Action. Tasikmalaya: Universitas Pendidikan Indonesia Kampus Tasikmalaya.

Peraturan Gubernur Jawa Barat. (2013). Peraturan Gubernur Jawa Barat Nomor 69 Tahun 2013 Tentang Pembelajaran Muatan Lokal Bahasa dan Sastra Daerah Pada Jenjang Satuan Pendidikan Dasar dan Menengah. Bandung: Pergub.

Peraturan Menteri Pendidikan Nasional. (2009). Peraturan Menteri Pendidikan Nasional Nomor 58 Tahun 2009 tentang Standar Pendidikan Anak Usia Dini. Jakarta: Depdiknas

Peraturan Pemerintah Pendidikan dan Kebudayaan No 137 tahub 2014 tentang Standar Nasional Pendidikan Anak Usia Dini.

Sugiyono. (2012). Metode Penelitian Kuantitaif, Kualitatif dan $R \& D$. Bandung: Alfabeta.

Sugiyono.(2013).Metode Penelitian Pendidikan. Bandung: Alfabeta.

Susilana, R \& Cepriyana.(2009). Media Pembelajaran.

Sya'ban. (2005). Teknik analisis data penelitian. Jakarta Timur: UHAMKA. 
Syahri, D. Inilah Strategi Agar Anak MenjadiBilingual Bahkan Multilingual [Online Tim Kartu Baca Flash Card. (2014). Metode Belajar Membaca dari -membaca-dari-glen- doman.ht
Glen Doman. [Online] Diakses dari dari http//:www.kartubacaflashcard.com/ metode-belajar 